\title{
Caa, a new South American genus of Gonolobinae (Apocynaceae: Asclepiadeae: Asclepiadoideae)
}

\author{
Caa, un nuevo género sudamericano de Gonolobinae \\ (Apocynaceae: Asclepiadeae: Asclepiadoideae)
}

\author{
Keller, Héctor A. ${ }^{1 *}$; Sigrid Liede-Schumann ${ }^{2}$ \\ 1 Instituto de Botánica del Nordeste, CONICET, Casilla de Correo 209, (3400) Corrientes, Argentina. \\ 2 Department of Plant Systematics, University of Bayreuth, 95440, Bayreuth, Germany. \\ * Autor corresponsal: ibone@unne.agr.edu.ar
}

\begin{abstract}
The phylogenetic analysis of the subtribe Gonolobinae allowed to determine the position of Matelea balansae Morillo \& Fontella, a taxon that was not related to the clade of the genus Matelea Aubl. sensu stricto, nor was grouped into other generic clades. This leads to the foundation of a new monotypic genus, Caa H. A. Keller \& Liede. Morphological information, complementary to the original diagnosis of the species, is included.
\end{abstract}

Keywords - Caa balansae; Matelea balansae; Paraguay; Argentina.

\section{RESUMEN}

El análisis filogenético de la subtribu Gonolobinae permitió determinar la posición de Matelea balansae Morillo \& Fontella, taxón que no resultó afín al clado del género Matelea Aubl. sensu stricto, ni tampoco se agrupó dentro de otros clados genéricos. Ello propicia la conformación de un nuevo género monotípico, Caa H.A. Keller \& Liede. Se incluye información morfológica complementaria a la diagnosis original de la especie.

Palabras clave - Caa balansae; Matelea balansae; Paraguay; Argentina.

Ref. bibliográfica: Keller, H. A.; Liede-Schumann, S. 2020. "Caa, a new South American genus of Gonolobinae (Apocynaceae: Asclepiadeae: Asclepiadoideae)". Lilloa 57 (1): 81-88. Fundación Miguel Lillo, Tucumán, Argentina. D.O.I.: doi.org/10.30550/j.lil/2020.57.1/6

> Recibido: 17/03/20 - Aceptado: 12/05/20

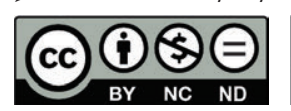




\section{INTRODUCTION}

The subtribe Gonolobinae (Apocynaceae: Asclepiadeae: Asclepiadoideae) has 45 genera distributed in tropical and subtropical regions of the New World (Endress, Meve, Middleton, Liede-Schumann, 2018). Its traditionally most species-rich genus, Matelea Aubl., has proved eclectic after successive phylogenies (Krings, Thomas, Xiang, 2008; Morillo, 2015; Mangelsdorff, Meve, Liede-Schumann, 2016). Therefore, recently several of its species have been segregated into new genera such as Atrostemma Morillo (2015), Graciemoriana Morillo (2015), Pseudolachnostoma Morillo (2012), Rhytidostemma Morillo (2013a), among others, or have been reintegrated into previously formed genera such as Ibatia Decne. (Morillo, 2013a) and Phaeostemma E. Fourn. (Morillo, 2013b).

Matelea balansae Morillo \& Fontella (2012) was described a few years ago on the basis of a specimen collected about a century and a half ago by the French botanist and explorer Gaspard Joseph Benedict Balansa, inside a subtropical forest in Caaguazú, Paraguay. The recent rediscovery of populations of this species, this time in Misiones province, Argentina (Keller, 2018), made it possible to incorporate the species into a phylogenetic analysis of the subtribe. This analysis reveals an isolated position of the species, distant from the clade of Matelea Aubl.s.s. and not integrated with other clades, promoting the formation of a new monotypic genus.

\section{MATHERIALS AND METHODS}

To assess the phylogenetic position of $M$. balansae, the 4-locus chloroplast marker dataset published by McDonnell, Parks, Fishbein (2018a, b) was used as a base, after removal of the too distant outgroup taxon Cynanchum ligulatum. For two accessions of $M$. balansae, trn L-F region and $r p s 16$ intron were created using standard primers, the trn $\mathrm{C}-r p o \mathrm{~B}$ spacer using using the primers trnC5'R and rpoB5'R and the $r p l 16$ intron using the primers rpl16-F71 and rpl16-R1661 (Table 1), as described in McDonnell et al. (2018a), resulting in eight sequences (Table 1).

To this dataset we applied maximum likelihood (ML) tree inference and nonparametric bootstrapping (BS) analysis as well as Bayesian Inference (BI). ML tree inference and BS relied on RAxML v. 8.2.10 (Stamatakis, 2014), as available on the CIPRES platform (Miller, Pfeiffer, Schwartz, 2010), which implements a general-time-reversible substitution model for nucleotides (Rodriguez, Oliver, Marin, Medina, 1990). For Bayesian inference, the analysis was run in MrBayes 3.2.2

Table 1. Sequences newly obtained for this paper.

\begin{tabular}{lcccc}
\hline Voucher & trnLF & trnC-rpoB & rps16 & rpl16 \\
\hline Keller \& Rojas 13747 (CTES) & LR782245 & LR782554 & LR782252 & LR782254 \\
\hline Keller et al. 13687 (CTES) & LR782243 & LR782553 & LR782251 & LR782253 \\
\hline
\end{tabular}


(Huelsenbeck \& Ronquist, 2001; Ronquist \& Huelsenbeck, 2003), as implemented on the CIPRES platform (Miller et al., 2010). The four partitions were unlinked, parameters estimated independently, and subjected to four simultaneous independent runs. Nucleotide substitution models were set to $\mathrm{HKY}+\mathrm{I}+\mathrm{G}$ for $\operatorname{trn} \mathrm{L}-\mathrm{F}$ and rps 16, and to GTR $+\mathrm{I}+\mathrm{G}$ for $\operatorname{trn} \mathrm{C}-\mathrm{rpoB}$ and $r p l 16$, following the results of found by modeltest[ng] (Darriba, Posada, Stamatakis, Flouris, 2017) as implemented on the CIPRES platform (Miller et al., 2010).

\section{RESULTS}

\section{Phylogeny}

Matelea balansae takes an isolated position in the Gonolobinae, sharing an unsupported clade with the South American Matelea reflexa, Schubertia and Macroscepis (Fig. 1) This clade is weakly supported sister to Matelea emmartinezii, the South American Matelea pedalis and the whole, well supported Gonolobus-clade. While the McDonnell et al. (2018 a, b) dataset is heavily biased toward Central American taxa, the isolation of M. balansae is maintained if other South American species are added to the dataset (Liede-Schumann et al., unpubl. results).

\section{Taxonomic treatment}

\section{Caa H. A. Keller \& Liede gen. nov.}

Ibatia Decne affine sed caulis cortice non suberoso, corona crassa, annuliformis. Typus.-Caa balansae (Morillo \& Fontella) H. A. Keller \& Liede

Climbing plants with a thin base, not suberified; young branches with mixed pubescence, consisting of multiseptate acicular trichomes and capitate glandular trichomes, adult branches puberulous. Leaves opposite, petiolate, with 3 digitiform colleters at the base of the abaxial face; petioles and veins of the abaxial face with pubescence similar to the young branches; blades oblong-lanceolate, base acute to cordate, obtuse to deeply cordate in juvenile specimens; apex acuminate, adaxial face glabrescent except for the base that is hairy; primary vein densely and tiny puberulent, abaxial face hairy, with 9-10 pairs of prominent lateral veins. Inflorescences cymose (3-8-flowers); peduncle longer than pedicels, bracts lanceolate, hairy. Flowers pedicellate; calyx lobes ovate-oblong, acuminate, hairy on the abaxial face, glabrous on the adaxial face, a colleter in each axile; corolla rotate, lobes broadly ovate, apex emarginate, conspicuously reticulate and glabrous on the adaxial face, shortly puberulous in the abaxial face; annular corona absent, staminal corona fleshy, annular and 5-lobed, lobes patent, reddish-brown, with two small violet ridges, one on each side, next to the suture with the adjacent lobe. Gynostegium subsessile, anthers dorsally bilobed. Pollinaria with corpusculum obtusely sagittate; caudicles hyaline; pollinia slightly ascending, convex on the outer face, internally concave; style-head pentagonal, slightly concave. Ovary with carpels asymmetrically pyriform, 


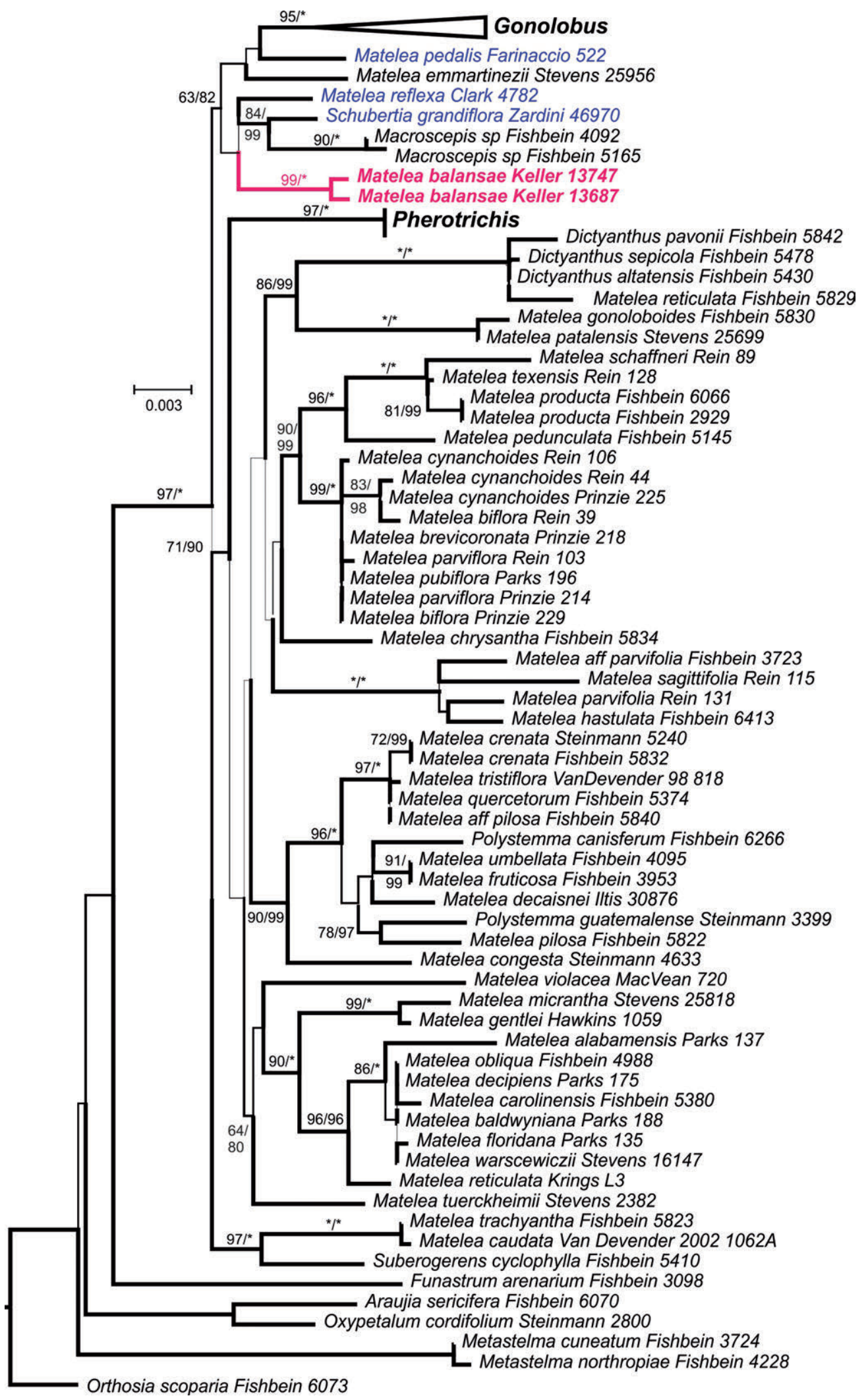

Fig. 1. Maximum likelihood tree of 77 Gonolobinae and 6 outgroup taxa, based on four chloroplast markers (trnL-F region, trnC-rpoB spacer, rp/16 and rps 16 introns). Well-supported monophyletic lineages recognized as undisputed genera have been summarized by triangles (Gonolobus, Pherotrichis). South American taxa are indicated in blue. Thickness of the branches corresponds to support, and support values above $60 \%$ BS have been written on the branches. * indicates $100 \%$ BS / PP. 
verrucose on the dorsal face. Fruits unknown, probably aculeate or muricate, given the texture of the carpels.

Genus monotypic with only three known occurrence locations, two current (in Misiones, Argentina) and one of very old data (type locality in Caaguazú, Paraguay) (Fig. 2). Within the Gonolobinae of southern South America (Morillo, Cáceres Moral, Keller, 2016; Morillo \& Keller, 2016; Keller \& Cáceres, 2017) Caa H.A. Keller \& Liede shares several characters with Ibatia Decne., a rotate corolla with lobes without frizzy margins, the absence of an annular corona, a gynostegial corona not adnate to the gynostegium, and without fimbriate lobes. However, Ibatia has main stems and even secondary branched suberified, while in Caa stems are barely lenticellate, even at the base. On the other hand, the gynostegial corona is annular, fleshy and thick in Caa, but lobate or cyathiform (cupuliform) in Ibatia.

\section{Etymology}

"Caa" (from Guaraní ka'a), is a common regional expression in Eastern Paraguay and Argentina (Misiones) that refers to the "primary forest" (environment where the only species of the genus proposed here grows), as well as to the "yerba mate" plant, Ilex paraguariensis A.St.-Hil. (Aquifoliaceae). In Guaraní mythology the toponym Caaguazú (type locality of the species), refers to a giant specimen of "yerba mate" that is capable of producing seeds of the most diverse plant species and that

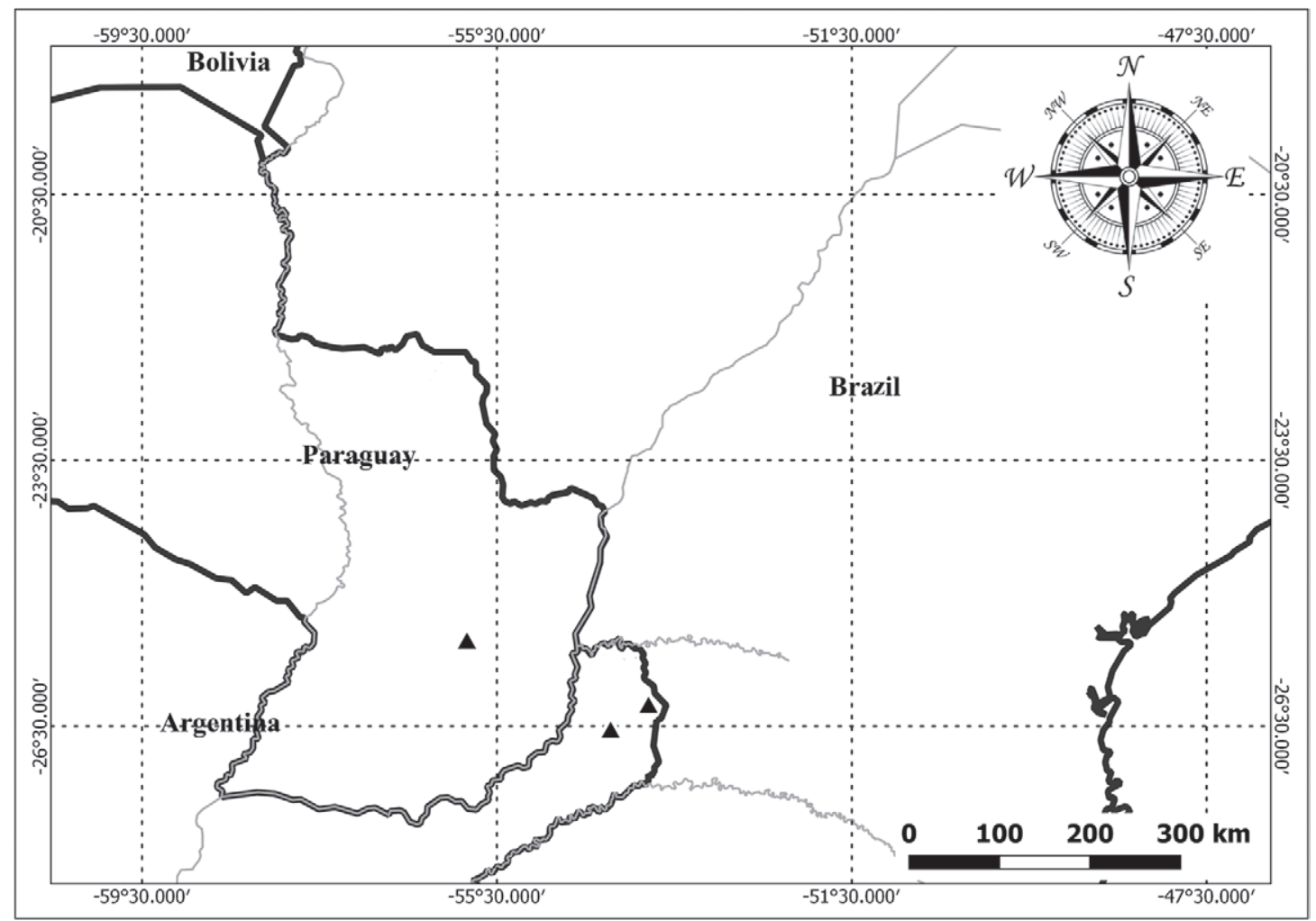

Fig. 2. Distribution map of Caa balansae H.A. Keller \& Liede. 
consequently constitutes a bank of diaspores to restore the forest in degraded areas (Keller, 2013).

Caa balansae (Fontella \& Morillo) H. A. Keller \& Liede comb. nov. (Fig. 2). Matelea balansae Morillo \& Fontella, Candollea 67: 187-189, 2012. Holotypus: PARAGUAY. Caaguazú: "Dans les forêts", XI.1874, Balansa, B. 1795 (P).

Description and iconography: Morillo \& Fontella (2012)

In the original description of the species the authors omit some details that are included here in the description of the genus. Among them the unsuberified base of the stems (Fig. 3A), the presence of long simple trichomes (Fig. 3B) that complete the bifarious pubescence of young stems, the inflorescences that can have more than three flowers (Fig. 3C), the absence of an annular corona, the coloration and the patent arrangement of the pieces of the gynostegial corona (Fig. 3D), and the characteristics of the ovary. These omissions are probably because the description was founded on a single, very old herbarium specimen, and no complete living plants were observed.

Aditional voucher: ARGENTINA, Misiones, Guaraní, Tres Reservas, 26³9'43,4”' S 54²'43,4” W, 20-XI-2017, fl, H.A. Keller. D. Attias E F.L. Rojas 13687 (CTES). Ídem., 15-I-2018, fl, H.A. Keller 13718 (CTES). Gral. Manuel Belgrano, Campinas de Américo, 26¹6’25,1' S - 5342’51,2”' O, 01-XII-2018, fl, H.A. Keller E L.F. Rojas 13747 (CTES).

\section{REFERENCES}

Darriba, D., Posada, D., Stamatakis, A. \& Flouris, T. (2017). ModelTest-NG: manual v.1.0.0. https://github.com/ddarriba/modeltest

Endress, M. E., Meve, U., Middleton, D. J. \& Liede-Schumann, S. (2018). Apocynaceae. In: J. W. Kadereit \& V. Bittrich (eds), Flowering plants. Eudicots. Apiales and Gentianales (except Rubiaceae), K. Kubitzki (ed.), Families and genera of vascular plants Vol. 15: 207-411. Springer, Cham.

Huelsenbeck, J. P. \& Ronquist, F. (2001). MRBAYES: Bayesian inference of phylogeny. Bioinformatics 17: 754-755.

Keller, H. A. (2013). Ka'aguachu: "la selva en un sólo árbol”. Una contribución de la mitología ava chiripa a la toponimia de la región guaranítica. Estudios Socioterritoriales: Revista de Geografía 13: 101-123.

Keller, H. A. (2018). Hallazgo de Matelea balansae (Apocynaceae) después de 143 años de su único registro. Paraguay Biodiversidad 5 (4): 45-47.

Keller, H. A. \& Cáceres Moral, S. (2017). Nuevo género y especie de Gonolobinae (Apocynaceae, Asclepiadoideae: Asclepiadeae) de Corrientes, Argentina. Lilloa 54 (2): 195-201. 


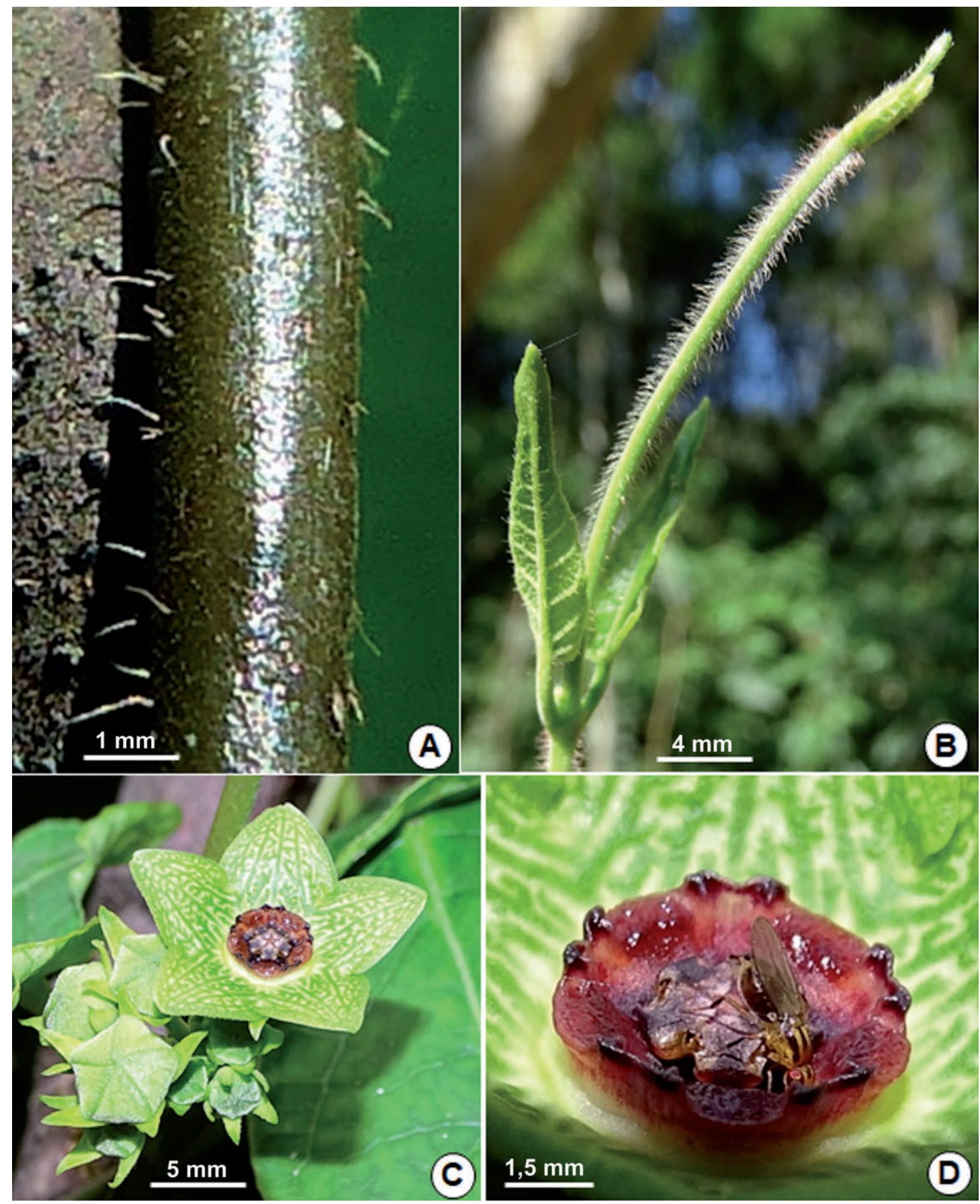

Fig. 3. Caa balansae H.A. Keller \& Liede. A) Stem near the base. B) Stem apex with long simple trichomes. C) Inflorescence. D) Gynostegial corona. Note the fly probing for nectar.

Krings A., Thomas D. T. \& Xiang, Q. (2008). On the generic circumscription of Gonolobus (Apocynaceae, Asclepiadoideae): Evidence from molecules and morphology. Systematic Botany 33 (2): 403-415.

Mangelsdorff R. D., Meve U. \& Liede-Schumann S. (2016). Phylogeny and circumscription of Antillean Anemotrochus, gen. nov., and Tylodontia (Apocynaceae: Asclepiadoideae: Gonolobinae). Willdenowia 46 (3): 443-474. 
McDonnell, A., Parks, M. \& Fishbein, M. (2018a). Data from: Multilocus phylogenetics of new world milkweed vines (Apocynaceae, Asclepiadoideae, Gonolobinae), Dryad, Dataset, https://doi.org/10.5061/dryad.1v154

McDonnell, A., Parks, M. \& Fishbein, M. (2018b). Multilocus Phylogenetics of New World Milkweed Vines (Apocynaceae, Asclepiadoideae, Gonolobinae). Systematic Botany 43: 77-96.

Miller, M. A., Pfeiffer, W. \& Schwartz, T. (2010). Creating the CIPRES Science Gateway for inference of large phylogenetic trees. In: Proceedings of the Gateway Computing Environments Workshop (GCE), 14 Nov. 2010, New Orleans, LA, pp 1-8.

Morillo, G. (2012). Aportes al conocimiento de las Gonolobinae (Apocynaceae-Asclepiadoideae). Pittieria 36: 13-57.

Morillo, G. (2013a). Aportes al conocimiento de las Gonolobinae II (Apocynaceae, Asclepiadoideae). Pittieria 37: 115-154.

Morillo, G. (2013b). Tres especies de Phaeostemma (Apocynaceae, Asclepiadoideae, Gonolobinae) nuevas para la ciencia. Bonplandia 22 (2): 203-215.

Morillo, G. (2015). Aportes al conocimiento de las Gonolobinae Parte III (Apocynaceae, Asclepiadoideae). Pittieria 39: 191-258.

Morillo, G. \& Fontella, J. (2012). Matelea balansae Morillo \& Fontella (Asclepiadaceae), una nueva especie para la flora de Paraguay. Candollea 67: 188-189.

Morillo, G. \& Keller H. A. (2016). Un nuevo género y dos nuevas combinaciones en las Gonolobinae (Apocynaceae, Asclepiadoideae). Bonplandia 25 (2): 129-143.

Morillo, G., Cáceres Moral, S. \& Keller, H. A. (2016). Cristobalia, un nuevo género sudamericano de Gonolobinae (Apocynaceae, Asclepiadoideae). Pittiera 40 (1): 122-143

Rodriguez, F., Oliver, J. L., Marin, A. \& Medina, J. R. (1990). The general stochastic model of nucleotide substitution. Fournal of Theoretical Biology 142: 485-501.

Ronquist, F. \& Huelsenbeck, J. P. (2003). MRBAYES 3: Bayesian phylogenetic inference under mixed models. Bioinformatics 19: 1572-1574.

Stamatakis, A. (2014). RAxML version 8: a tool for phylogenetic analysis and postanalysis of large phylogenies. Bioinformatics 30: 1312-1313. 